\title{
ESO-1 Reactive Autologous Peripheral Blood Lymphocyte
}

National Cancer Institute

\section{Source}

National Cancer Institute. ESO-1 Reactive Autologous Peripheral Blood Lymphocyte. NCI

Thesaurus. Code C38119.

Human peripheral blood lymphocytes (PBL) isolated from a patient, exposed to the tumor-associated protein ESO-1 in vitro, and then transferred back to the same patient to targ et tumor cells expressing ESO-1. ESO-1 is a human self-antigen expressed by melanomas. The ESO-1 gene encodes several MHC class I- and MHC class II-restricted epitopes that may activate cytotoxic T-cell-mediated tumor destruction. ( $\mathrm{NCl04)}$ 